\title{
Preface: Theory and practice of harmonisation
}

The topic of this book is the theory and practice of harmonisation. This is an ambitious topic, and this book can only make a limited contribution. The contributors come from different fields of law, and develop a number of common themes.

Harmonisation is an important feature of the modern legal system. Harmonisation of the laws of the Member States is a core instrument of the European Union. Many international treaty obligations entail duties to adopt conform legislation and ensure conform application. International and regional human rights treaties provide important examples of this. There is a considerable scholarly literature on different harmonisation issues, but not bringing together the outcome of this scholarship in a comparative analysis or in developing more general theory on the harmonisation process or different aspects of it. There is a further need for bringing together scholars of a range of legal, social science and humanities disciplines, including from within the law, general legal theory or jurisprudence, constitutional law, comparative law, international law, human rights law and EU law, and the different national and international legal areas most affected by harmonisation. Contributions are made in integration studies, international relations, European studies, and political theory. Moving freely over the boundaries that divide the law, and the fragmented scholarly disciplines, may usefully combine perspectives in interdisciplinary and multidisciplinary scholarship. In this way one may provide models for, and improve, the understanding of the harmonisation process. This book is mainly by legal scholars and the wider perspectives and the combination of perspectives from interdisciplinary and multidisciplinary scholarship is left outstanding. The following points will demonstrate how rich and demanding scholarship in one discipline, the legal, can be.

The procedures for adopting the harmonising instrument, and for subsequent amendments to it, are under rapid development. In the EU, the legislative procedures are a central constitutional concern, and are subject to continuous reform. Different treaty regimes offer new and alternative mechanisms.

The forms of the harmonising instrument offer much variety and innovation. International treaties and conventions do not follow universal models. In the EU, there is an important difference between directives and regulations, but also the regulation, which has direct effect without any legislative transposition, often 
requires different implementation measures to have its effect in national law. Some main types of directives are minimum standards directives, maximum standards directives, framework directives, and directives in the process of open method of coordination. The relationship to the fundamental freedoms in the EC Treaty is another issue. For international treaties and conventions, there is the relationship to customary international law and other treaties and conventions.

The role of international financial institutions, such as the World Bank and the IMF, in legal harmonisation across a wide field, is controversial and requires further analysis to be fully understood. Harmonisation, aid and development bring up many related issues.

Informal harmonisation processes, outside the intergovernmental fora, are of increasing importance. The role of model codes, principles and other outcomes of such processes is another field of study. Their interaction with the intergovernmental organs, and their reception in contract practice or directly by national legislators or courts merits further attention. Important examples here are Principles, Definitions and Model Rules of European Private Law. Draft Common Frame of Reference (DCFR), 2009 (see also the Interim Outline Edition, 2009), the research carried out by the Study Group on a European Civil Code (the von Bar Group) and the Research Group on EC Private Law (Acquis Group) and other academic and scholarly projects and their relationship with more formal EU procedures: see for instance the European Commission's 2003 Action Plan on a More Coherent European Contract Law which merits study.

Transposition in national law takes different forms in national legislation, and the procedures vary as well. Harmonisation has affected the form of national legislation, and the sources of law in the national legal system. Court practice in the application of harmonised law follows yet other principles and patterns. The response in case law to the new sources of law that can assist in promoting uniformity, or in some fields the ways in which the lack of such sources are compensated for, is of particular interest. The use of judgments from other international or national jurisdictions is one current issue. Informal networks of judges cooperate across jurisdictional boundaries in the application of international instruments, assisting one another in finding sources and practical solutions to the uniformity problems.

Amendment and monitoring of the transposition and subsequent practice under national law is another area where there in some areas are highly developed regimes, and in others practically nothing following the adoption of a convention. There are models involving an independent international monitoring body, or more judicialised institutions, or combinations of supranational monitoring and court institutions. Novel forms of institutionalised peer review have developed over the last couple of decades.

Enforcement and sanctioning provide other challenges, closely related to monitoring and amendment. 
The experiences with harmonised regimes provide extensive material which is well suited for research. In the EU, there is an emerging scholarship comparing the transposition of directives in different national laws. This provides a basis for the Review of the Consumer Acquis, which is another of the harmonisation projects of the European Commission, currently limited to eight directives, including the Consumer Sales Directive and the Unfair Terms Directive, leaving aside other directives in the consumer field such as the Consumer Credit Directive, the Unfair Commercial Practices Directive and the Product Liability Directive. Maximum harmonisation and the use of mandatory rules in the directives may have had a profound effect on the private law of the Member States, which if it has had such an effect, remains underexplored.

The international conventions in the long established tradition for harmonisation of commercial law provide another field of emerging scholarship: see for instance, the United Nations Convention on Contracts for the International Sale of Goods, 1980, the UNCITRAL Model Law on International Commercial Arbitration 1985, UNIDROIT's Principles of International Commercial Contracts, the EBRD's Secured Transactions Project, and the ICC's Uniform Customs and Practice for Documentary Credits.

In comparative law there is a current discourse about legal transplants. There is also a challenge to the idea of convergence between national legal systems and traditions. One issue here is to link the theoretical models that have emerged here with the scholarship on harmonisation in different fields.

Most of the chapters in this book are based on the 2008 WG Hart Workshop where they were presented and discussed. 'The theory and practice of harmonisation' was the topic of that year's workshop (which is organised annually at the Institute of Advanced Legal Studies, the University of London). Since then, there have been many important developments that the authors have had scarce opportunity to include in their papers over the period of development of this book. In the field of EU regulation this has especially been true for the finalisation of the DCFR in 2009, the Directive on Consumer Rights in 2011, and the newly proposed Regulation on a common EU Sales Law in October 2011. In transnational commercial law, UNCITRAL have finalised their bid for a convention on carriage of goods by sea. In English Law, the BIS are developing a new registration of company charge regime and there is a new Secured Transactions Law Reform project founded by Professor Sir Roy Goode; both fuelled by inspiration from other legal regimes. Harmonisation is difficult to keep up with, and we ask that readers keep this in mind when reading the individual chapters.

The editors offer their thanks to the contributors to the book, who continue to work in this complex field, undaunted by these rapid developments. We would also like to thank Belinda Crothers, who organised the 2008 WG Hart Workshop with her usual great skill and patience, and Sir Francis Jacobs who 
was the source of generous advice, as on so many previous occasions, and who graciously opened and chaired the first day of the workshop. Finally, we would like to thank Nick Foster who originally conceived the bid for the 2008 WG Hart Conference, but then had to leave it to us for health reasons. Had it not been for Nick's concept, braving the treacherous depths of the theory of harmonisation, this book would not be here today.

Mads Andenas and Camilla Baasch Andersen 